\title{
Evaluasi Efektivitas dan Keamanan Penggunaan Obat Anestesi Umum di RS PKU Muhammadiyah Yogyakarta
}

\author{
Istiqoma Dewi Kurniawati ${ }^{1}$, Zullies Ikawati ${ }^{2}$, Inayati ${ }^{3}$ \\ ${ }^{1}$ RSUD Tuban, Jawa Timur \\ ${ }^{2}$ Fakultas Farmasi, Universitas Gadjah Mada \\ ${ }^{3}$ Unit Farmasi, RS PKU Muhammadiyah Yogyakarta
}

\begin{abstract}
Anesthesia is given to more than 75 million surgical patients annually, wordwide. An ideal anesthetic drug would induce anesthesia smoothly and rapidly while allowing for prompt recovery after its administration is discontinued. The drug would also prossess a wide margin of safety and be devoid of adverse effects. The objective of the study was to get an overview on use of general anesthesia at PKU Muhammadiyah hospital, Yogyakarta which included aspects of dose induction relevance, effectiveness of general anesthesia based on onset dan duration recovery and safety based on cardiovascular and respiratory side effects which happened due to induction anesthesia.The study used descriptive case series design carried out prospectively. Data were obtained from observation of elective surgery patient in Instalasi Bedah Sentral at PKU Muhammadiyah hospital, Yogyakarta. Sample were collected by concecutive sampling methods on Maret-Juni 2010. Onset, duration recovery were monitored after induction anesthesia. Systolic and diastolic blood pressure, heart rate, saturation were monitored 0 minute before induction and 5 minute after induction anesthesia.From 84 patient, as many as 72,62\% were relevant dose with induction and 27,38\% were irrelevant dose. Effectivity anesthesia based on onset was $100 \%$ effective Recovery from isoflurane was 4-11 minute faster than with sevoflurane and 14 minute faster than hallotane. Cardiovascular side effect was not significant between relevant and irrelevant dose Induction. No respiratory side effect was found.
\end{abstract}

Key word : induction anesthesia, case serries, concecutive sampling

\begin{abstract}
ABSTRAK
Anestesi diberikan lebih dari 75 juta pasien operasi di dunia setiap tahun. Suatu anestetika yang ideal dapat menimbulkan efek anestesi dengan tenang dan cepat serta memungkinkan waktu pemulihan yang lebih cepat. Obat tersebut juga harus punya batasan keamanan yang luas dan tidak menimbulkan dampak yang keras. Di RS PKU Muhammadiyah, Propofol banyak digunakan sebagai induksi anestesi dan anestesi pemeliharaan yang bervariasi.Evaluasi penggunaan anestesi umum bertujuan untuk mengetahui kesesuian pemberian dan dosis induksi anestesi umum, efektivitas berdasarkan awitan dan waktu pemulihan, keamanan berdasarkan kejadian efek samping kardiovaskular dan pernafasan pada fase induksi.Penelitian ini adalah penelitian observasional dengan cara mengamati kasus-kasus operasi elektif, pengumpulan data dilakukan secara prospektif dan data diolah secara analitik pada pasien bedah di Instalasi Bedah Sentral
\end{abstract}


RS PKU Muhammadiyah Yogyakarta. Sampel diambil dengan metode concecutive sampling pada bulan maret-juni 2010. Pasien yang mendapat anestesi umum diamati keamanan anestesi berdasarkan awitan dan waktu pemulihan dari pemberian anestesi umum dan diobservasi efek samping induksi anestesi berdasarkan nilai tekanan darah sistolik, tekanan darah diastolik, nadi dan saturasi pada menit ke 0 sebelum induksi dan menit ke 5 setelah induksi. dari total 84 pasien, induksi sesuai $100 \%$, Dosis induksi sesuai sebesar 72,62\%, tidak sesuai sebesar 27,38\%. Efektifitas berdasarkan awitan $100 \%$ efektif dan waktu pemulihan isofluran lebih cepat 4-11 menit dibanding sevofluran, dan lebih cepat1-4 menit dibanding halotan. Secara statistik tidak ada perbedaan bermakna jumlah pasien yang mengalami efek samping kardiovaskular (nilai p>0,05). Tidak terjadi efek samping pernafasan pada semua kelompok induksi.

Kata Kunci : induksi anestesi, case serries, concecutive sampling

\section{PENDAHULUAN}

Anestesi telah diberikan pada lebih dari 75 juta pasien operasi di dunia setiap tahun (Apfel et al., 2004). Anestesi umum merupakan keadaan tidak terdapatnya sensasi yang berhubungan dengan hilangnya kesadaran yang reversibel (Neal, 2006). Anestesi dapat dibagi menjadi tiga fase yaitu fase induksi, pemeliharaan dan sadar kembali dari anestesi (Mycek, 2001).Suatu anestesi yang ideal dapat menimbulkan anestesi dengan tenang dan cepat serta memungkinkan pemulihan segera setelah penanganan selesai. Obat tersebut juga harus punya batasan keamanan yang luas dan tidak menimbulkan dampak yang merugikan (Katzung, 2002).

Anestesi umum yang poten diberikan secara inhalasi atau suntikan intravena (Mycek, 2001). Awitan dan durasi merupakan efek farmakokinetik yang paling penting pada anestetik intravena ketika digunakan sebagai induksi anestesi. Anestesi intravena dapat menghasilkan berbagai manfaat dan efek samping (seperti depresi atau stimulasi kardiovaskular, nyeri pada sisi injeksi, mual dan muntah, depresi atau stimulasi pernafasan, eksitasi atau perlindungan central nervous system, supresi adenocorticoid). Pemilihan anestesi intravena sebaiknya berdasarkan karakteristik pasien dan kondisi yang berhubungan dengan operasi dan biaya (Koda-Kimble, 2009).

Anestesi yang digunakan di RS PKU Muhammadiyah adalah anestesi intravena dan anestesi inhalasi. Penggunaan propofol sebagai induksi anestesi intravena cukup banyak digunakan dan ketika induksi anestesi pasien mendapat premedikasi yang bervariasi. Selama prosedur pembedahan pasien bedah mendapat anestesi inhalasi yang bervariasi sebagai anestesi pemeliharaan. Berdasarkan permasalahan di atas, maka dilakukan penelitian lebih lanjut mengenai kesesesuaian dosis pemberian induksi anestesi, perbandingan efektivitas dan kejadian efek samping serta mengetahui efektivitas dari anestesi pemeliharaan.

\section{METODOLOGI PENELITIAN}

Penelitian ini merupakan penelitian observasional dengan cara mengamati kasus-kasus operasi elektif yang sebelumnya dilakukan anestesi umum pada periode maret-juni 2010, penggumpulan data 
dilakukan secara prospektif dan data diolah secara analitik. Pemilihan sampel dilakukan dengan metode consecutive sampling.

Cara kerja:

Pasien yang akan menjalani pembedahan elektif dengan anestesi umum diseleksi dan ditentukan oleh klinisi berdasarkan kriteria inklusi. Sebelum di induksi dengan anestesi, dilakukan pencatatan kondisi preoperasi, data karakteristik awal yang terdiri dari umur, diagnosa pembedahan, obat dan dosis anestesi, tekanan darah sistolik, diastolik, laju nadi dan saturasi oksigen. Pasien mendapat perlakuan induksi anestesi diamati awitan diobservasi tekanan darah sistolik, tekanan darah diastolik, nadi dan saturasi pada menit ke 0 sebelum induksi dan menit ke 5 setelah induksi. Pasien yang mendapat anestesi pemeliharaan diamati durasi anestesi dan waktu pemulihan. Data yang diperoleh dari observasi di lembar observasi.

\section{HASIL DAN PEMBAHASAN Profil Pasien}

Sampel pada penelitian ini adalah sebanyak 84 terdiri dari $41,38 \%$ laki-laki dan sisanya $56,62 \%$ adalah perempuan. Jenis induksi yang banyak dilakukan di RS PKU Muhammadiyah Yogyakarta adalah induksi dengan pramedikasi midazolam dengan nilai persentase sebesar 38,10\% dan induksi yang paling sedikit dilakukan adalah induksi dengan premedikasi midazolam dan fentanyl hanya sebesar $11,90 \%$.

\section{Profil Induksi Anestesi dan Pemeliharaan Anestesi}

Rumatan anestesi yang paling sering digunakan adalah sevofluran dengan persentase sebesar $48,81 \%$ dan yang paling sedikit digunakan adalah rumatan dengan kombinasi dua anestesi inhalasi yaitu kombinasi antara halotan dan sevofluran, kombinasi sevofluran dan isofluran dengan persentase masing-masing sebessar 3,57\%. Sevofluran merupakan anestesi inhalasi golongan halogen eter yang memiliki keuntungan waktu pulih dari anestesi yang lebih cepat dibandingkan dengan isofluran, sehingga lebih banyak digunakan.

\section{Kesesuaian Induksi Anestesi}

Kesesuaian dosis anestesi induksi pada operasi elektif di RS PKU Muhammadiyah sebesar $72,62 \%$ dan ketidaksesuaian dosis sebesar $27,38 \%$. Ketidaksesuaian tertinggi terjadi pada pasien di atas > 59 tahun yaitu sebesar 19,05\% . Ketidaksesuaian karena pasien mendapat dosis yang berlebih.

Tabel 1. Rata-rata Nilai Awitan pada masing-masing Kelompok Induksi Anestesi Intravena berdasarkan Kesesuaian Induksi Anestesi pada Pasien Bedah Elektif di Instalasi Bedah RS PKU Muhammadiyah Yogyakarta Periode Maret-Juni 2010.

\begin{tabular}{|c|c|c|c|}
\hline \multirow{2}{*}{ Induksi } & Rata-rata nilai awitan (detik) & \multirow{2}{*}{ Nilai-p } \\
\cline { 2 - 3 } & Dosis Sesuai & $\begin{array}{c}\text { Dosis Tidak } \\
\text { sesuai }\end{array}$ & \\
\hline Hanya propofol & $31,96 \pm 11,72$ & $39,43 \pm 12,92$ & 0,382 \\
\hline $\begin{array}{c}\text { Premedikasi midazolam \& } \\
\text { propofol }\end{array}$ & $37,16 \pm 8,86$ & $30,86 \pm 6,47$ & \\
\hline $\begin{array}{c}\text { Premedikasi fentanyl \& } \\
\text { propofol }\end{array}$ & $37,71 \pm 8,28$ & $39,80 \pm 8,84$ & \\
\hline $\begin{array}{c}\text { Premedikasi midazolam, } \\
\text { fentanyl \& propofol }\end{array}$ & $38,33 \pm 16,18$ & $33,25 \pm 14,93$ & \\
\hline \multicolumn{2}{|c|}{$\begin{array}{c}\text { Range awitan=9-51 detik } \\
\text { Semua data dinyatakan dalam rerata } \pm \text { simpangan baku }\end{array}$}
\end{tabular}


Tabel 2. Persentase Pasien yang Mengalami Efek Samping Hipertensi pada Masing-masing Kelompok Induksi Berdasarkan kesesuaian Induksi pada Pasien Bedah Elektif di Instalasi Bedah RS PKU Muhammadiyah Yogyakarta Periode Maret-Juni 2010.

\begin{tabular}{|c|c|c|c|c|c|}
\hline Induksi & $\begin{array}{c}\text { Kesesuaian } \\
\text { Dosis Propofol }\end{array}$ & $\mathbf{n}$ & $\begin{array}{c}\text { Jumlah } \\
\text { Pasien yang } \\
\text { mengalami } \\
\text { efek samping } \\
\text { hipertensi }\end{array}$ & $\begin{array}{c}\text { \% pasien yang } \\
\text { mengalami } \\
\text { efek samping } \\
\text { hipertensi }\end{array}$ & Nilai $-p$ \\
\hline \multirow{2}{*}{$\begin{array}{c}\text { Hanya } \\
\text { propofol }\end{array}$} & Sesuai & 23 & 1 & 4,34 & \multirow[t]{2}{*}{0,13} \\
\hline & Tidak sesuai & 7 & 2 & 28,57 & \\
\hline \multirow{2}{*}{$\begin{array}{c}\text { Premedikasi } \\
\text { midazolam \& } \\
\text { propofol }\end{array}$} & Sesuai & 25 & 3 & 12,00 & \multirow[t]{2}{*}{1,00} \\
\hline & Tidak sesuai & 7 & 0 & 0,00 & \\
\hline \multirow{2}{*}{$\begin{array}{c}\text { Premedikasi } \\
\text { fentanyl \& } \\
\text { propofol }\end{array}$} & Sesuai & 7 & 0 & 0,00 & \multirow[t]{2}{*}{-} \\
\hline & Tidak sesuai & 5 & 0 & 0,00 & \\
\hline \multirow{2}{*}{$\begin{array}{c}\text { Premedikasi } \\
\text { midazolam, } \\
\text { fentanyl \& } \\
\text { propofol }\end{array}$} & Sesuai & 6 & 0 & 0,00 & \multirow[t]{2}{*}{0,40} \\
\hline & Tidak sesuai & 4 & 1 & 25,00 & \\
\hline
\end{tabular}

\section{Efektivitas Penggunaan Anestesi Umum}

Penentuan efektivitas induksi anestesi umum intravena berdasarkan nilai awitan hasil pengamatan pada masing-masing pasien sampel penelitian dibandingkan dengan nilai awitan propofol yang telah ada diliteratur. Awitan dari propofol yang diberikan secara bolus (tergantung dengan dosis) kira-kira 9-51 detik dan rata-rata 30 detik (Lacy et al., 2008). Obat induksi bolus disuntikkan dengan kecepatan antara 30-60 detik (Latief et al., 2001).

Secara statistik tidak ada perbedaan yang bermakna nilai awitan antara induksi dengan dosis propofol sesuai dan tidak sesuai (nilai $p=0,382$, nilai $p>0,05$ ). Dari data awitan di atas menunjukkan bahwa semua jenis induksi baik yang sesuai maupun yang tidak sesuai terbukti efektif pada pasien dengan nilai awitan masuk dalam range stadar nilai awitan dalam literatur yaitu 9-51 detik. Awitan dari anestesi dipengaruhi oleh kecepatan injeksi anestesi, injeksi yang cepat menyebabkan konsentrasi propofol dalam darah lebih tinggi setelah injeksi (Zhenk et al., 1998).Durasi operasi menujukkan waktu pasien diberikan anestesi pemeliharaan disesuaikan dengan proses berjalannya operasi. Dari hasil penelitian menujukkan bahwa waktu pemulihan isofluran pada masing-masing kelompok premedikasi memiliki waktu pemulihan yang lebih cepat 4 menit hingga 11 menit dibanding dengan sevofluran, dan isofluran lebih cepat 1 menit hingga 4 menit dibanding dengan halotan. Kejadian efek samping hipertensi tertinggi pada pasien yang mendapat induksi anestesi hanya menggunakan propofol (Dosis Tidak sesuai) sebesar $28,57 \%$. Secara statistik tidak terdapat perbedaan bermakna kejadian efek samping hipertensi pada induksi dengan dosis propofol sesuai dan tidak sesuai (nilai $p>0,05)$.

\section{Keamanan Anestesi Umum}

Keamanan anestesi umum dinilai dari efek samping yang terjadi pada fase induksi, bukan pada fase pemeliharaan atau pada fase pemulihan. Karena, efek samping hipertensi dapat disebabkan karena nyeri akibat pembedahan, iritasi pipa trakhea, cairan infuse berlebihan, buli-buli penuh atau aktivasi saraf simpatis karena hipoksia, hiperkapnia dan asidosis. Hipotensi sendiri bisa disebabkan karena pendarahan, terapi 
cairan kurang adekuat, hilangnya cairan ke rongga ketiga, keluaran air kemih belum diganti, kontraksi miokardium kurang kuat atau tahanan vaskular ferifer menurun.

Penurunan nilai saturasi (hipoksemia, $\mathrm{SpO} 2<90 \mathrm{mmHg}$ ) bisa disebabkan karena pernafasan pasien lambat dan dangkal (hipoventilasi). Pernafasan lambat bisa disebabkan karena opioid dan dangkal sering diakibatkan oleh pelumpuh otot yang masih bekerja (Latief et al., 2001). Dalam anestesi dikatakan hipotensi apabila penurunan tekanan darah $>25 \%$ dari nilai awal.

Hipotensi dikategorikan berat bila penurunan tekanan darah sistolik dibawah $70 \mathrm{mmHg}$ dan memerlukan intervensi. Begitu juga dengan hipertensi dinyatakan hipertensi apabila tekanan darah $>25 \%$ dari awal (Wahyuni, 2007). Propofol merupakan obat induksi anestesi dengan efek samping penurunan tekanan darah 25-40\% (Poltak, 2006).

Kejadian efek samping hipertensi tidak terjadi pada pasien yang menerima induksi anestesi menggunakan premedikasi fentanyl baik yang sesuai maupun yang tidak sesuai karena penambahan fentanyl untuk induksi untuk meningkatkan efek analgesia selama prosedur operasi dan menurunkan respon hipertensi karena intubasi (Cork et al., 1984; Dahlgren et al., 1981; Martin et al., 1982). Hal ini juga sama pada penelitian yang dilakukan oleh Baley dimana pada pasien yang menerima induksi propofol dengan fentanyl tidak ditemukan kejadian hipertensi (Bailey et al., 1990).

Kejadian efek hipertensi dapat disebabkan karena nyeri injeksi setelah pemberian induksi propofol dan efek intubasi. Iritasi propofol pada vena menyebabkan aktivasi protease yang akan memecah kininogen jaringan plasma menjadi bradikinin nonpeptida yang merupakan substansi nyeri yang sangat kuat. Nyeri akibat pemberian propofol dipengaruhi oleh: kecepatan injeksi, tempat penyuntikan pada vena, pemberian narkotik sebelum injeksi propofol, pengenceran larutan propofol/ konsentrasi, pendinginan larutan propofol sebelum diinjeksikan. Sedangkan mekanisme timbulnya nyeri itu sendiri belum diketahui secara pasti (Siahaan, 2003).

Efek samping hipertensi bisa disebabkan karena nyeri pada saat intubasi.

Tabel 3. Persentase Pasien yang Mengalami Efek Samping Hipertensi serta Takikardi pada Masing-masing Kelompok Induksi Berdasarkan kesesuaian Induksi pada Pasien Bedah Elektif di Instalasi Bedah RS PKU Muhammadiyah Yogyakarta Periode Maret-Juni 2010.

\begin{tabular}{|c|c|c|c|c|c|}
\hline Induksi & $\begin{array}{c}\text { Kesesuaian } \\
\text { Dosis } \\
\text { Propofol }\end{array}$ & $\mathrm{N}$ & $\begin{array}{c}\text { Jumlah } \\
\text { Pasien yang } \\
\text { mengalami } \\
\text { efek samping } \\
\text { hipertensi \& } \\
\text { takikardi }\end{array}$ & $\begin{array}{l}\text { \% pasien yang } \\
\text { mengalami } \\
\text { efek samping } \\
\text { hipertensi \& } \\
\text { takikardi }\end{array}$ & Nilai-p \\
\hline \multirow{2}{*}{$\begin{array}{c}\text { Hanya } \\
\text { propofol }\end{array}$} & Sesuai & 23 & 1 & 4,34 & \multirow[t]{2}{*}{1,00} \\
\hline & Tidak sesuai & 7 & 0 & 0,00 & \\
\hline \multirow{2}{*}{$\begin{array}{c}\text { Premedikasi } \\
\text { midazolam \& } \\
\text { propofol }\end{array}$} & Sesuai & 25 & 2 & 8,00 & \multirow[t]{2}{*}{1,00} \\
\hline & Tidak sesuai & 7 & 0 & 0,00 & \\
\hline \multirow{2}{*}{$\begin{array}{c}\text { Premedikasi } \\
\text { fentanyl \& } \\
\text { propofol }\end{array}$} & Sesuai & 7 & 0 & 0,00 & \multirow[t]{2}{*}{-} \\
\hline & Tidak sesuai & 5 & 0 & 0,00 & \\
\hline \multirow{2}{*}{$\begin{array}{c}\text { Premedikasi } \\
\text { midazolam, } \\
\text { fentanyl } \& \\
\text { propofol }\end{array}$} & Sesuai & 6 & 0 & 0,00 & \multirow[t]{2}{*}{-} \\
\hline & Tidak sesuai & 4 & 0 & 0,00 & \\
\hline
\end{tabular}


Tabel 4. Persentase Pasien yang Mengalami Efek Samping Hipotensi Berdasarkan Kesesuaian Induksi pada Masing-masing Kelompok pada Pasien Bedah Elektif di Instalasi Bedah RS PKU Muhammadiyah Yogyakarta Periode Maret-Juni 2010.

\begin{tabular}{|c|c|c|c|c|c|}
\hline Induksi & $\begin{array}{c}\text { Kesesuaian } \\
\text { Dosis } \\
\text { Propofol }\end{array}$ & $\mathrm{N}$ & $\begin{array}{c}\text { Jumlah } \\
\text { Pasien yang } \\
\text { mengalami } \\
\text { efek samping } \\
\text { hipotensi }\end{array}$ & $\begin{array}{l}\text { \% pasien yang } \\
\text { mengalaini } \\
\text { efek samping } \\
\text { hipotensi }\end{array}$ & Nilai- $p$ \\
\hline \multirow{2}{*}{$\begin{array}{c}\text { Hanya } \\
\text { propofol }\end{array}$} & Sesuai & 23 & 5 & 21,74 & \multirow[t]{2}{*}{1,00} \\
\hline & Tidak sesuai & 7 & 1 & 14,29 & \\
\hline \multirow{2}{*}{$\begin{array}{c}\text { Premedikasi } \\
\text { midazolam \& } \\
\text { propofol }\end{array}$} & Sesuai & 25 & 5 & 20,00 & \multirow[t]{2}{*}{0,32} \\
\hline & Tidak sesuai & 7 & 3 & 42,84 & \\
\hline \multirow{2}{*}{$\begin{array}{c}\text { Premedikasi } \\
\text { fentanyl \& } \\
\text { propofol }\end{array}$} & Sesuai & 7 & 1 & 14,29 & \multirow[t]{2}{*}{1,00} \\
\hline & Tidak sesuai & 5 & 1 & 20,00 & \\
\hline \multirow{2}{*}{$\begin{array}{l}\text { Premedikasi } \\
\text { midazolam, } \\
\text { fentanyl \& } \\
\text { propofol }\end{array}$} & Sesuai & 6 & 0 & 0.00 & \multirow[t]{2}{*}{-} \\
\hline & Tidak sesuai & 4 & 0 & 0,00 & \\
\hline
\end{tabular}

Tabel 5. Persentase Pasien yang Mengalami Efek Samping Hipotensi dan Bradikardi Berdasarkan Kesesuaian Induksi pada Masing-masing Kelompok pada Pasien Bedah Elektif di Instalasi Bedah RS PKU Muhammadiyah Yogyakatta Periode Maret-Juni 2010.

\begin{tabular}{|c|c|c|c|c|c|}
\hline Induksi & $\begin{array}{c}\text { Kesesuaian } \\
\text { Dosis } \\
\text { Propofol }\end{array}$ & n & $\begin{array}{c}\text { Jumlah } \\
\text { Pasien yang } \\
\text { mengalaini } \\
\text { efek samping } \\
\text { hipotensi \& } \\
\text { bradikardi }\end{array}$ & $\begin{array}{l}\text { \% pasien yang } \\
\text { mengalami } \\
\text { efek samping } \\
\text { hipotensi \& } \\
\text { bradikardi }\end{array}$ & Nilai- $p$ \\
\hline \multirow{2}{*}{$\begin{array}{c}\text { Hanya } \\
\text { propofol }\end{array}$} & Sesuai & 23 & 1 & 4,35 & \multirow[t]{2}{*}{1,00} \\
\hline & Tidak sesuai & 7 & 0 & 0,00 & \\
\hline \multirow{2}{*}{$\begin{array}{c}\text { Premedikasi } \\
\text { midazolam \& } \\
\text { propofol }\end{array}$} & Sesuai & 25 & 0 & 0,00 & \multirow[t]{2}{*}{-} \\
\hline & Tidak sesuai & 7 & 0 & 0,00 & \\
\hline \multirow{2}{*}{$\begin{array}{c}\text { Premedikasi } \\
\text { fentanyl \& } \\
\text { propofol }\end{array}$} & Sesuai & 7 & 2 & 28,57 & \multirow[t]{2}{*}{1,00} \\
\hline & Tidak sesuai & 5 & 1 & 20,00 & \\
\hline \multirow{2}{*}{$\begin{array}{c}\text { Premedikasi } \\
\text { midazolam, } \\
\text { fentanyl \& } \\
\text { propofol }\end{array}$} & Sesuai & 6 & 0 & 0,00 & \multirow[t]{2}{*}{-} \\
\hline & Tidak sesuai & 4 & 0 & 0,00 & \\
\hline
\end{tabular}

Hal ini terlihat pada kejadian efek samping hipertensi tidak terjadi pada pasien yang menerima induksi anestesi menggunakan premedikasi fentanyl baik yang sesuai maupun yang tidak sesuai karena penambahan fentanyl untuk induksi untuk meningkatkan efek analgesia selama prosedur operasi dan menurunkan respon hipertensi karena intubasi (Cork et al., 1984; Dahlgren et al., 1981; Martin et al., 1982). Hal ini juga sama pada penelitian yang dilakukan oleh Baley dimana pada pasien yang menerima induksi propofol dengan fentanyl tidak ditemukan kejadian hipertensi (Bailey et al., 1990).

Hipertensi dengan takikardi selama induksi anestesi umum bisa disebabkan karena nyeri, hipoventilasi, pendarahan intrakranial dan iskemik myokard tetapi tidak semuannya dapat menujukkan gejala klinik. Penelitian sebelumnya menujukkan bahwa propofol dapat menginduksi vasokontriksi dan dosis rendah propofol 
Tabel 6. Persentase Pasien yang Mengalami Efek Samping Takikardi pada Masing-masing Kelompok Induksi berdasarkan Kesesuaian Induksi pada Pasien Bedah Elektif di Instalasi Bedah RS PKU Muhammadiyah Yogyakarta Periode Maret-Juni 2010.

\begin{tabular}{|c|c|c|c|c|c|}
\hline Induksi & $\begin{array}{c}\text { Kesesuaian } \\
\text { Dosis } \\
\text { Propofol }\end{array}$ & $\mathbf{n}$ & $\begin{array}{c}\text { Jumlah } \\
\text { Pasien yang } \\
\text { mengalami } \\
\text { efek samping } \\
\text { takikardi }\end{array}$ & $\begin{array}{c}\% \text { pasien yang } \\
\text { mengalami } \\
\text { efek samping } \\
\text { takikardi }\end{array}$ & Nilai- $p$ \\
\hline \multirow{2}{*}{$\begin{array}{c}\text { Hanya } \\
\text { propofol }\end{array}$} & Sesuai & 23 & 1 & 4,35 & \multirow[t]{2}{*}{0,13} \\
\hline & Tidak sesuai & 7 & 2 & 28,57 & \\
\hline \multirow{2}{*}{$\begin{array}{c}\text { Premedikasi } \\
\text { midazolam \& } \\
\text { propofol }\end{array}$} & Sesuai & 25 & 4 & 16,00 & \multirow[t]{2}{*}{1,00} \\
\hline & Tidak sesuai & 7 & 1 & 14,29 & \\
\hline \multirow{2}{*}{$\begin{array}{c}\text { Premedikasi } \\
\text { fentanyl \& } \\
\text { propofol }\end{array}$} & Sesuai & 7 & 0 & 0,00 & \\
\hline & Tidak sesuai & 5 & 0 & 0,00 & \\
\hline \multirow{2}{*}{$\begin{array}{l}\text { Premedikasi } \\
\text { midazolam, } \\
\text { fentanyl } \& \\
\text { propofol }\end{array}$} & Sesuai & 6 & 0 & 0,00 & \multirow[t]{2}{*}{0,40} \\
\hline & Tidak sesuai & 4 & 1 & 25,00 & \\
\hline
\end{tabular}

Tabel 7. Persentase Pasien yang Mengalami Efek Samping Bradikardi pada Masing-masing Kelompok Induksi berdasarkan Kesesuaian Induksi pada Pasien Bedah Elektif di Instalasi Bedah RS PKU Muhammadiyah Yogyakarta Periode Maret-Juni 2010.

\begin{tabular}{|c|c|c|c|c|c|}
\hline Induksi & $\begin{array}{c}\text { Kesesuaian } \\
\text { Dosis } \\
\text { Propofol }\end{array}$ & $\mathbf{n}$ & $\begin{array}{c}\text { Jumlah } \\
\text { Pasien yang } \\
\text { mengalami } \\
\text { efek samping } \\
\text { Bradikardi }\end{array}$ & $\begin{array}{c}\text { \% pasien yang } \\
\text { mengalami } \\
\text { efek samping } \\
\text { bradikardi }\end{array}$ & Nilai- $p$ \\
\hline $\begin{array}{c}\text { Hanya } \\
\text { propofol }\end{array}$ & Sesuai & 23 & 3 & 13,04 & \multirow{2}{*}{1,00} \\
\cline { 2 - 5 } & Tidak sesuai & 7 & 0 & 0,00 & \multirow{2}{*}{1,00} \\
\hline $\begin{array}{c}\text { Premedikasi } \\
\text { midazolam \& } \\
\text { propofol }\end{array}$ & Sesuai & 25 & 1 & 4,00 & \multirow{2}{*}{1,00} \\
\cline { 2 - 6 } & Tidak sesuai & 7 & 0 & 0,00 & \\
\hline $\begin{array}{c}\text { Premedikasi } \\
\text { fentanyl \& } \\
\text { propofol }\end{array}$ & Sesuai & 7 & 2 & 28,57 & \\
\cline { 2 - 5 } $\begin{array}{c}\text { Premedikasi } \\
\text { midazolam, } \\
\text { fentanyl \& } \\
\text { propofol }\end{array}$ & Sesuai & 6 & 0 & 0,00 & \\
\cline { 2 - 5 } & Tidak sesuai & 4 & 0 & 0,00 & \\
\hline
\end{tabular}

untuk mencegah terjadinya hipotensi selama induksi dapat menyebabkan hipertensi dengan takikardi (Imanaka et al., 2009). Propofol menghambat respon hemodinamik terhadap laringoskopi dan intubasi (Omoigui, 1995). Penurunan tekanan darah dapat disebabkan oleh vasodilatasi dan penurunan kotraktilitas myocardial. Dilaporkan oleh pemilik produk propofol kejadian efek samping hipotensi setelah pemberian induksi propofol sebesar 53\%.
Efek samping hipotensi lebih minimal pada induksi propofol dengan menggunakan premedikasi fentanyl, dan kejadian efek samping hipotensi tidak terjadi pada induksi dengan premedikasi midazolam dan fentanyl baik yang sesuai maupun yang tidak sesuai.

Berdasarkan penelitian yang dilakukan oleh Short, TG., et al, ketika diberikan induksi anestesi menggunakan propofol dengan fentanyl tanpa pemberian midazolam akan dapat meningkatkan hipotensi pada saat postinduksi (TG Short, 
Tabel 7. Persentase Pasien yang Mengalami Efek Samping Bradikardi pada Masing-masing Kelompok Induksi berdasarkan Kesesuaian Induksi pada Pasien Bedah Elektif di Instalasi Bedah RS PKU Muhammadiyah Yogyakarta Periode Maret-Juni 2010.

\begin{tabular}{|c|c|c|c|c|c|}
\hline Induksi & $\begin{array}{c}\text { Kesesuaian } \\
\text { Dosis } \\
\text { Propofol }\end{array}$ & $\mathbf{n}$ & $\begin{array}{c}\text { Jumlah } \\
\text { Pasien yang } \\
\text { mengalami } \\
\text { efek samping } \\
\text { Bradikardi }\end{array}$ & $\begin{array}{c}\% \text { pasien yang } \\
\text { mengalami } \\
\text { efek samping } \\
\text { bradilaardi }\end{array}$ & Nilai- $p$ \\
\hline \multirow{2}{*}{$\begin{array}{c}\text { Hanya } \\
\text { propofol }\end{array}$} & Sesuai & 23 & 3 & 13,04 & \multirow[t]{2}{*}{1,00} \\
\hline & Tidak sesuai & 7 & 0 & 0,00 & \\
\hline \multirow{2}{*}{$\begin{array}{c}\text { Premedikasi } \\
\text { midazolam \& } \\
\text { propofol }\end{array}$} & Sesuai & 25 & 1 & 4,00 & \multirow[t]{2}{*}{1,00} \\
\hline & Tidak sesuai & 7 & 0 & 0,00 & \\
\hline \multirow{2}{*}{$\begin{array}{c}\text { Premedikasi } \\
\text { fentanyl \& } \\
\text { propofol }\end{array}$} & Sesuai & 7 & 2 & 28.57 & \multirow[t]{2}{*}{1,00} \\
\hline & Tidak sesuai & 5 & 1 & 20,00 & \\
\hline \multirow{2}{*}{$\begin{array}{c}\text { Premedikasi } \\
\text { midazolam, } \\
\text { fentanyl } \& \\
\text { propofol }\end{array}$} & Sesuai & 6 & 0 & 0,00 & \\
\hline & Tidak sesuai & 4 & 0 & 0,00 & \\
\hline
\end{tabular}

1991., McClune, 1992., Billard, 1994). Begitu juga dengan penelitian yang dilakukan Billard, dkk., Induksi propofol dengan fentanyl dapat meningkatkan hipotensi postinduksi. Penurunan tekanan darah sistolik sebesar $40 \%$ selama induksi anestesi dengan propofol secara bolus dan fentanyl 2 ìg/kg (Billard et al., 1994). Ketika ditambahkan midazolam, hipotensi tidak mengalami peningkatan secara signifikan dibandingkan dengan kelompok yang hanya mendapatkan fentanyl (Short et al., 1991; McClun et al., 1991; Tzabar et al., 1996). Penurunan tekanan darah pada fase induksi dipengaruhi oleh dosis dan kecepatan pemberian anestesi (Peacock et al; 1992; Claeys et al; 1988; Kazama et al; 1998).

Penggunaan propofol dalam induksi anestesi dapat menurunkan tekanan arteri dan tekanan vaskular sistemik, Tekanan darah sistolik menurun setelah dimulainya induksi, tekanan diastolik turun setelah 60 detik dari awal induksi anestesi dan akan turun hingga menit ke 210 setelah induksi. Mekanisme penurunan tekanan darah setelah pemberian propofol masih diperdebatkan, tetapi hal ini dari penurunan pre- dan afterload tanpa kompensasi peningkatan heart rate dan cardiac output (Claeys et al; 1988; Schmidt et al; 1999).

Kejadian hipotensi dan bradikardi persentase tertinggi terjadi pada kelompok pasien yang mendapat induksi anestesi dengan fentanyl (Dosis Sesuai) 28,57\%, (Dosis Tidak Sesuai) sebesar 20,00\%. Tidak terdapat perbedaan yang bermakna kejadian efek samping hipotensi dan bradikardi pada antara induksi dengan dosis propofol yang sesuai dan tidak sesuai (nilai $p>0,05$ ). Pada umumnya tidak ada hubungan antara hipotensi dan bradikardi (Hug, dkk; 1993). Penurunan tekanan darah pada fase induksi dipengaruhi oleh dosis dan kecepatan pemberian anestesi (Peacock et al; 1992; Claeys, et al; 1988; Kazama et al; 1998). Mekanisme penurunan tekanan darah setelah pemberian propofol masih diperdebatkan, tetapi hal ini menghasilkan pre- dan afterload tanpa kompensasi peningkatan heart rate dan cardiac output (Claeys et al; 1988; Schmidt et al; 1999).

Takikardi tertinggi terjadi pada kelompok pasien yang mendapat induksi dengan premedikasi midazolam dan fentanyl yaitu sebesar $26,00 \%$. Tidak terdapat perbedaan yang bermakna kejadian efek 
samping hipotensi dan bradikardi pada antara induksi dengan dosis propofol yang sesuai dan tidak sesuai (nilai $p>0,05$ ). Diketahui bahwa propofol dapat memiliki efek konduksi pada nodus atrioventricular (Kannan et al., 2002). Kannan, et al., melaporkan bahwa terdapat kasus takikardi supraventrikular pada pasien dewasa. Kasus ini terjadi pada pasien dengan jenis kelamin laki-laki dan berusia 68 tahun dan memiliki berat kira-kira $80 \mathrm{~kg}$ yang mendapat dosis propofol $100 \mathrm{mg}$ dan tidak menerima pelemas otot.

Propofol menginduksi bradikardi itu umum terjadi. Persentase bradikardi teringgi terjadi pada kelompok pasien yang mendapat induksi propofol dengan pramedikasi fentanyl (Dosis Sesuai) 28,57\% dibandingkan dengan induksi dengan premedikasi fentanyl yang sesuai yaitu 20,00\%. Tidak terjadi kejadian efek samping bradikardi pada kelompok pasien yang mendapat induksi dengan premedikasi midazolam dan fentanyl. Secara statistik jumlah pasien yang mengalami efek samping bradikardi antara induksi dengan dosis sesuai dan dosis tidak sesuai pada masingmasing kelompok induksi menujukkan perbedaan yang tidak bermakna (nilai $p$ $>0,05$ ).

Berdasarkan penelitian Hug (1993) bradikardi secara signifikan lebih umum terjadi pada pasien yang mendapat propofol dengan kombinasi golongan opioid (fentanyl). Kejadian bradikardi tidak terjadi pada pasien yang mendapat induksi dengan pramedikasi midazolam dan fentanyl baik yang sesuai maupun yang tidak sesuai. Severe bradikardi pernah dilaporkan karena penggunaan propofol dengan fentanyl, succinylcholine. (Baraka A et al., 1990).

Efek samping pernafasan yang diamati pada penelitian ini adalah efek pada saturasi pernafasan. Saturasi oksigen merupakan persentase hemoglobin dalam oksigen pada suatu waktu pengukuran. Berdasarkan ketentuan ASA pada tanggal 27 oktober 2004 dan diamandemen pada tanggal 21 oktober 2009, pada pasien yang mendapat anestesi umum propofol harus dimonitor saturasi oksigen secara teratur.

Efek samping terhadap saturasi dilakukan dengan monitor saturasi oksigen (SpO2). Kriteria hipoksemia : hipoksemia ringan jika saturasi oksigen ( $\mathrm{SpO} 2)$ 86-90\%, hipoksemia sedang jika SpO2 81-85\%, hipoksemia beratjika nilai SpO2 < 81\% (Anonim, 2009). Efek samping terhadap saturasi pada pasien tidak ditemukan selama penggunaan Propofol selama fase induksi karena pasien mendapat suplai oksigen secara berkecukupan selama dilakukan induksi anestesi dan sebelum induksi jika saturasi pasien kurang dari 90.

Perbandingan dengan penelitian yang dilakukan oleh Drumoond et al., hasilnya menujukkan bahwa lebih dari 200 pasien bedah, fentanyl mempengaruhi hasil akhir. Depresi pernafasan, sehingga end-tidal fraksi karbondioksida lebih besar $1 \%$. Saturasi oksigen juga berkurang, 27\% pasien yang menerima fentanyl menujukkan saturasi oksigen < 92\% (Drummond et al., 2010). Berdasarkan laporan efek samping pada tanggal 25 agustus 2010 pada 10175 pasien yang menerima propofol 395 pasien (3,88\% dari total pasien yang menerima propofol) mengalami penurunan saturasi oksigen.

\section{KESIMPULAN}

Dari total 84 pasien, induksi sesuai $100 \%$, Dosis induksi sesuai sebesar 72,62\%, tidak sesuai sebesar 27,38\%. Efektifitas berdasarkan onset $100 \%$ efektif dan waktu recovery isofluran lebih cepat 4-11 menit 
dibanding sevofluran, dan lebih cepat1-4 menit dibanding halotan. Secara statistik tidak ada perbedaan bermakna jumlah pasien yang mengalami efek samping kardiovaskular (nilai $p>0,05$ ). Tidak terjadi efek samping pernafasan pada semua kelompok induksi.

\section{DAFTAR PUSTAKA}

Apfel, CC., Korttila, K., Abdalla, M et al., 2004, A Factorial Trial of Six Interventions for the Prevention of Postoperative Nausea and Vomiting, Vol.350 No.24.

Bailey, PL., Wilbrink, J., Zwanikken, P et al., Narcotic Intravenous anesthetic, Anesthesia, $3^{\text {rd }}$ edition, Edited by Miller RD, New-York, Churchill Livingstone, 1990, pp 281-366

Baraka, 1998, Severe Bradycardia following Prop ofol-Suxamethonium Sequence. Br J Anaesth;61:482-3, 61.

Billard, V., Moulla, F., Megnigbeto, A et al, 1994., Hemodynamic Response to Induction and Intubation: Propofol/ Fentanyl Interaction. Anesthesiology 1994;81:1384-93.

Claeys, MA., dkk., Haemodynamic Changes During Anesthesia Induced and Maintenaned with Propofol. $\mathrm{Br}$ JAnaesth 1988;60:3-9

Cork, RC., Weiss, JL., Hameroff, SR., Bentley et al., 1984, Fentanyl Preloading for Rapid-sequence Induction of Anesthesia, Anest Analg 63:60-64.

Dahlgren, N., Messeter, K., 1981. Treatment of Stress Response to Laringoscopy and Intubation with Fentanyl. Anesthesia 36: 1022-1026.
Drummond, G.B., Lafferty, B., 2010, Oxygen saturation decrease acutely when opioids are given during anaesthesia, British Journal of Anaesthesia 2010 104(5):661-663; 10.1093/bja/aeq076

Hug, CC., McLeskey., Nahrwold, ML et al., 1993, Hemodinamic Effects of Propofol: Data from Over 25000 Patients, Departement of Anesthesiology, Emory University School of Medicine, Atlanta, Georgia, PMID: 8214693 [PubMed-indexed for MEDLINE]

Kannan, S., Sherwood, N., 2002, Termination of supraventricular tachycardia by propofol, $b r J$ Anaesth 2002; 88:874-5

Katzung, B.G., 2002, Farmakologi : Dasar dan Klinik, Buku 2, Edisi 8, Penerbit Salemba Medika, Jakarta, hal.129-148.

Kazama, T., Ikeda, K., Morita, K., 1998, The Pharmacodynamic Interaction between Propofol and Fentanyl with Respect to the Suppresion of Somatic or Hemodinamic Responses to Skin Insision, Peritonium Insision, and Abdominal Wall Retraction. Anesthesiology 1998;89:894-906

Martin, DE., Rosenberg, H., Aukburg, SJ et al., 1982, Low-dose Fentanyl Blunts Circulatory Response to Tracheal Intubation. Anesth Analg 61:680-684, 1982.

Mycek, M.J., 2001, Farmakologi Ulasan Bergambar, Edisi II, Penerbit Widya Media, Jakarta, hal.110

Neal, 2006, Farmakologi Medis, Edisi kelima, Penerbit Erlangga, Jakarta, hal 52. 
Peacock, JE., Spier, SPW., McLauchlan et al., 1992, Infution of Propofol to Identifity Smallest Effective Dose for Induction of Aneshesia in Young and Elderly Patients. Br. J Anaesth 1992;69:363-7.

Poltak, Marihot., 2006, Daya Guna Premedikasi Oral Midazolam 0,1 mg/ kgbb dalam Menurunkan Dosis Induksi Propofol pada Operasi Elektif Dewasa, 02/1779/II-SP/0087, RT 617_96.

Schmidt, C., Roosens, C., Struys, M et al., 1999, Contractility in Humans after Coronary after Surgery. Anaeshtisiology 1999;91:58-70

Short, TG., Plummer, JL., Chui, MB et al., 1991, Propofol and Midazolam Act Synergistically in Combination. $\mathrm{Br} \mathrm{J}$ Anaesth 1991; 67:539-45.

Stachnik, J. dan Bonk, M. E, 2006, Inhaled Anesthetic Agents. American Journal of Health-System Pharmacy, 63, 623634.

White, PF., Romero, G., 2006, Nonopioid Intravenous Anesthesia, In: Barash PG et al., eds, Clinical Anesthesia, Philadelphia: Lippincott William \& Wilkins; 2006: 334.

Zheng, D., Upton, RN., Martinez, AM., Grant, C dan Ludbrook, GL., 1998, The Influence of the Bolus Injection Rate of Propofol on its Cardiovascular Effects and Peak Blood Concentration in Sheep, $A \& A$ Vol. 86 no 5 1109-1115 